\title{
Study of Diabetic Hypertensive Nephropathy in the Local Population of Pakistan
}

\author{
Samreen Riaz and Saadia Shahzad Alam \\ University of the Punjab, Lahore, Pakistan and FPGMI, Shaikh Zayed Hospital Lahore \\ Pakistan
}

\section{Introduction}

Diabetes mellitus is a metabolic disorder that is characterized by high blood sugar and it is because of either problem in insulin secretion (type 1- $\beta$ cell destruction) or either because of combination of insulin resistance or improper insulin secretion to compensate (type 2). (Riaz, S. 2009)

\section{Mechanism of action}

Despite ingestion of dietary carbohydrates, serum glucose level remain relatively steady throughout the day. This requires the concerted actions of several different tissues. Pancreatic $\beta$-cells, for example, secrete insulin in response to the elevation in glucose that occur after eating. Insulin promotes glucose disposal in adipose tissue and muscle, and also prevents the liver from producing more glucose by suppressing glycogenolysis and gluconeogenesis. In the fasting state, low insulin levels combined with elevated counterregulatory hormones such as glucagon, adrenaline and corticosteroids promote hepatic glucose production. Recently, evidence has emerged that the brain coordinates many of these effects as well, through direct and indirect glucose sensing and neural outputs to peripheral organs.

Diabetes results from the dysregulation of multiple glucoregulatory hormones that normally acto to maintain glucose homeostasis. For example any defect in insulin production lead to improper regulation of glucose in the blood and result in diabetes. Similarly in patients with type 1 and type 2 diabetes, post prandial glucagon secretion is abnormally elevated. This inappropriate secretion of glucagon leads to excess hepatic glucose production and is important contributor to postprandial hyperglycemia in patients with diabetes.

\section{Insulin resistance}

Deficient insulin action results from inadequate insulin secretion or decrease the tissue response.Insulin resistance is define as lack of sufficient insulin receptors, in target tissue, defect in intracellular transport of glucose and or an altered insulin secondary pattern that is dys-synchronization between pancreatic $\beta$ cell release of insulin and the body's insulin requirement.( Defronzo, R.A., 1992) 


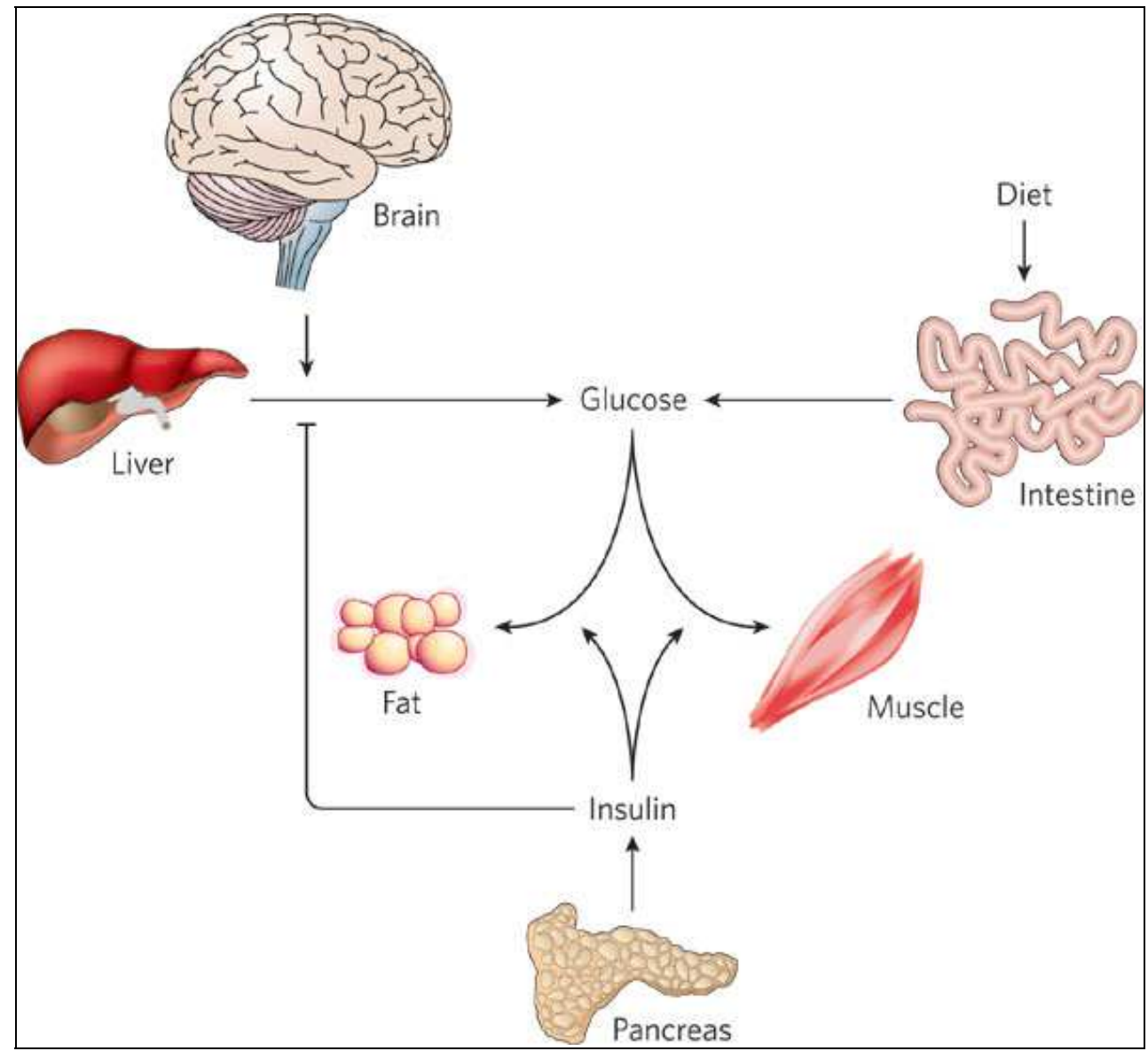

Fig. 1. Glucose homeostasis

\section{Prevalence of diabetes}

As the prevalence of diabetes is exponentially increasing in many parts of world. It is estimated by WHO that until 2025 there will be 300 million diabetics from which $75 \%$ will be from developing countries.

In terms of number of people with diabetes mellitus by the year 2025 USA will be most leading country while Pakistan will be at forth country in the list after China and USA. (Jawaid, S. A., 2002). According to a new publication released by World Health Organization (WHO) and International Diabetes Federation (IDF) 3.2million deaths occur because of diabetes. ( Launch of "Diabetes action Now" 5May 2004Igeneva) And it is six leading cause of death by disease world wide.

There are several factors that contribute in increasing the prevalence of diabetes thy include: 
- Increase population growth

- $\quad$ Aging

- Urbanization

- Increasing prevalence of obesity

- Increasing prevalence of physical inactivity. (King, H., and Rewers, M., 1993.)

\section{Etiologic classification of diabetes mellitus}

The World Health Organization (WHO) Expert Committee on diabetes in 1980 and later WHO study group on diabetes mellitus approve the recommendation of National Diabetes Data Group (NDDG). (Report of a WHO Study Group1985) They divide diabetes mellitus into 4 different types :

1. Insulin dependant diabetes mellitus(IDDM)

2. Non-insulin dependant diabetes mellitus(NIDDM)

3. Gestational diabetes mellitus(GDM)

4. Other types

\subsection{Type 1 diabetes}

\subsubsection{Immune mediated diabetes}

This is also called as insulin dependand diabetes or juvenile onset diabetes. In this type autoimmunity cause the destruction of $\beta$-cells of pancreas. Marker for immune mediated diabetes include islet cell autoantibodies (ICAs), autoantibodies to insulin (IAA), autoantibodies to glutamic acid decarboxylase(GAD65) and autoantibodies to tyrosine phosphatase $1 \mathrm{~A}-2$ and $1 \mathrm{~A}-2 \beta$. For survival these patients are insulin dependant.

\subsubsection{Idiopathic diabetes}

In this case there is no known reason and these patients have mostly African or Asian origin. This is strongly inherited but not HLA associated. They are also insulin dependant.

\subsection{Type 2 diabetes}

This is also known as non-insulin dependant diabetes mellitus or adult onset diabetes. For survival of these patients insulin is not necessary.In these patients obesity is a major cause of insulin resistance while increase age and physical inactivity are also important factors.Ketoacidosis occur because of stress of other infection. it has strong genetic predisposition (Riaz, S. 2009).

\subsection{Other specific types of diabetes}

\subsubsection{Genetic defect of $\beta$ cell}

This is also called as maturity onset diabetes of young (MODY), as it appears before age 25 years and it is characterized by defect in $\beta$ cell function. In some families inabilityto convert proinsulin to insulin while in some cases mature insulin molecule production. 


\subsubsection{Genetic defect in insulin action}

Metabolic abnormalities cause the mutations in insulin receptor. For example in type A insulin resistance, leprechaunism, Rabson, Mendenhall syndrome are two pediatric syndromes that have mutation in insulin receptor and have extreme insulin resistance.

\subsubsection{Disease of exocrine pancreas}

Injury to pancreas can cause diabetes and it include pancreatitis, trauma, infection, pancreatectomy and pancreatic carcinoma

\section{Endocrinopathy}

Excess amount of some hormone like growth hormone, cortisol, glucagon, apinephrine can cause diabetes as they are antagonize insulin action.

\section{Drug or chemical induce diabetes}

Impairinsulin secretion or insulin resistance also cause by some drugs. For example vacor (rat poison), pentamidine, nicotinic acid, glucocorticoids, thyroid hormones, diazoxide, $\beta$ adrenergic agonists, dilantin, a interferon and other.

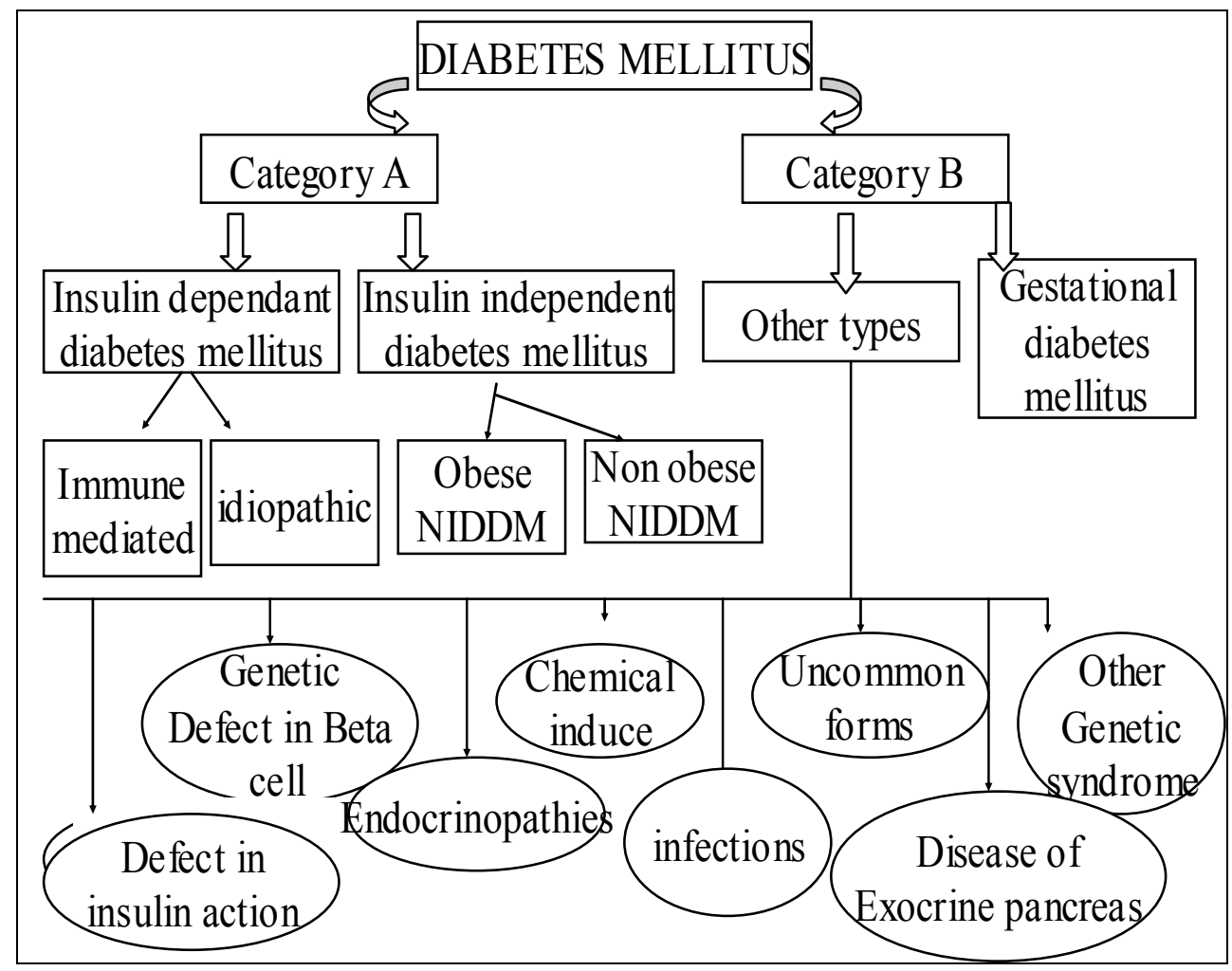

Fig. 2. Etiologic classification of diabetes mellitus 


\section{Infection}

Some viruses cause the $\beta$ cell destruction. They include congenital rubella, coxsackie virus $\mathrm{B}$, cytomegalovirus, adenovirus and mumps.

\section{Uncommon}

Two conditions are known for it.

1. in stiffman syndrome glutamic acid decaroxylase autoantibodies are produced.

2. antiinsulin receptor antibodies bind with insulin receptor and these antibodies are present in some autoimmune disease and systemic lupus erythemoatosus.

\subsubsection{Other genetic syndrome}

Incidence of diabetes mellitus also increase with many genetic syndromes. For example Down syndrome, Turner's syndrome, Kline-felter's syndrome, Wolfram's syndrome, Huntington's chorea, Porphyria etc. Autopsy shows the absence of $\beta$ cells.

\subsection{Gestational diabetes mellitus}

Impair glucose tolerance normally occur in third trimester of pregnancy. (O'Sullivan and Mahan 1964) Complications of gestational diabetes mellitus increase risk of cesarean delivery and chronic hypertension.

\section{Long term complications of diabetes}

Long term complications of diabetes include the:

- $\quad$ retinopathy (potential loss of vision)

- nephropathy (renal failure)

- $\quad$ peripheral neuropathy (risk of foot ulcer)

- autonomic neuropathy cause gastrointestinal, genitourinary and cardiovascular symptoms

- $\quad$ periodontal disease(disease of bone and tissue supporting teeth)

- and sexual dysfunction. (Report of the Expert Committee on the Diagnosis and classification of Diabetes Mellitus)

\subsection{Nephropathy}

Nephropathy is a damage or disease of the kidney. It may be because of several factors and diabetes is one of the major factor of nephropathy.

\subsection{Diabetes and nephropathy}

Diabetes nephropathy is microvascular complication that associate with diabetes it slowly deteriorate the kidney and lead to end stage renal disease that is chronic and irreversible. Diabetic nephropathy need for chronic dialysis or a kidney transplant.

Since recovery is irreversible so early detection is effective prevention tool. (American diabetes association diabetic nephropathy diabetic care 2002; 25 (supplement) 


\subsection{Symptoms of diabetic hypertensive nephropathy}

Diabetic hypertensive nephropathy is characterized by

- $\quad$ polyuria (frequent urination)

- polydipsia and polyphagia (excess thirst and food intake)

- weight loss

- blurred vision

- $\quad$ and susceptibility to infection

- Biochemical changes in diabetic patients

- Glycation of macromolecules and tissue proteins

- Risk of cardiovascular peripheral vascular and cerebrovascular disease

- Abnormalities of lipoproteins metabolism (hypertension)

- Psychosocial dysfunction also produce because of social impact of diabetes. (Report of the Expert Committee on the Diagnosis and classification of Diabetes Mellitus)

\subsection{Prevalence of diabetic hypertensive nephropthy}

$40 \%$ of type 1 and $20 \%$ type 2 diabetic patients develop the nephropathy. While prevalence of hypertension in type 2 diabetic patients is estimated at $50 \%$ with one estimated as high as $74 \%$. (Riaz, S et al. 2009)

\subsection{Sources of urinary proteins}

The total urinary protein excreted

- $\quad 48 \%$ was contained in sediments

- $\quad 49 \%$ was soluble

- $\quad$ and the remaining 3\% was in exosomes(Zhou, H., 2006)

\subsubsection{Soluble proteins}

\subsubsection{Glomerular filteration of plasma proteins}

From glomerular filteration urinary soluble proteins are derived. In proximal tube most of the proteins and peptides are scavenged by highly specialized apical uptake process and this process involves receptor like recognition of peptide molecules. (Christensen, E. I., and Birn, H. 2001; Christensen, E. I. 2002). So in final urine the mount of soluble proteins changes with change concentration in blood plasma, change in glomerular filteration and change in proximal tubule scavenging system.

Based on mechanism change in excretion rate of protein indicative of systemic disease, globular disease or tubular disease.

\subsubsection{Epithelial cell secretion of soluble proteins}

Some proteolytically cleaved membrane bound proteins also present in urine. One of them is Tamm-Horsfall protein. It is most abundant protein in urine and if it is not removed its presence interfare with detection of other proteins. 


\subsubsection{Solid phase components}

Solid phase components consist of sediments that can be precipitated at low centrifugation. It mainly consist of epithelial cells. They are important for diagnostic information because increase number of these cells indicates the renal disease.

\subsubsection{Exosomes}

Exosomes are derived from glomerular podocytes, renal tubule cells from proximal and distal nephron segments and transitional epithelial cell lining the urinary drainage system.

Exosome are the internal vesicles of multivasculr bodies and transfer to extracellular fluid by fusion of outer membrane of multivesicular bodies with plasma membrane. (Pisitkun, T., 2004)

\subsection{Urinary protein marker for diabetic nephropathy}

Urinary protein profiling can reveal changes in excretion rates of specific proteins that can have predictive value in the clinical arena, for example

- In the early diagnosis of disease

- In classification of disease with regard to likely therapeutic responses

- In assessment of prognosis

- $\quad$ and in monitoring response to therapy

\subsection{Up-regulated urinary proteins in diabetic nephropathy}

\subsubsection{Albumin and non-immunoreactive albumin}

The molecular weight of albumin is $71,658 \mathrm{KDa}$. Clinically, diabetic nephropathy can be diagnosed when albumin is detected in the urine (albumin excretion 30-300 mg/day). The presence of albumin in the urine is considered predictive of the subsequent development and clinical progression of diabetic nephropathy. (The Microalbuminuria Collaborative Study Group) Microalbuminuria is not specific for diabetic nephropathy , since albumin can also be detected in some other pathological conditions and the prevalence of microalbuminuria in the general population is rather high. Finally, microalbuminuria is a poor predictor of diabetic nephropathy.(Riaz, S et al., 2010)

\subsection{2 a1B-Glycoprotein}

The molecular weight of a1B-Glycoprotein is $54,239 \mathrm{KDa}$. It is homologous to the immunoglobulin supergene family and contains five Ig-like $\mathrm{V}$ type (immunoglobulin-like) domains. a1B-glycoprotein binds heme and transports it to the liver for breakdown and iron recovery, after which the free hemopexin returns to the circulation. a1B-Glycoprotein has possible role in the autoimmunity involved in nephropathy. Its levels have been described to be higher in type 2 diabetes, its relationship with C-reactive protein is lost in both type 1 and type 2 diabetes, and its levels are independently determined by triacylglycerol and the diabetic state (Van Campenhout, A., et al 2006). This molecule can potentially act as a toxic protease, leading in the rat to proteinuria and glomerular alterations (Bakker, W.W., et al 2005). Although there were no direct references to its possible effects in humans with 
diabetes or nephropathy, because diabetes is an inflammatory condition associated with iron abnormalities, it can be postulated that a1B-Glycoprotein is altered in diabetes.

\subsubsection{Zinc- $\alpha 2-g l y c o p r o t e i n$}

The molecular weight of Zinc-a2-glycoprotein is 34,223 KDa. . This protein stimulates lipid degradation in adipocytes and may also bind polyunsaturated fatty acids. Zinc-a2glycoprotein was the second most abundant urinary protein in diabetic nephropathy. An earlier study of type 2 diabetes described zinc-a2-glycoprotein and three other proteins, a1acid glycoprotein, a1- microglobulin, and IgG, as specific markers for diabetic nephropathy (Jain, S., et al 2005).

\subsection{4 a2-HSglycoprotein precursor (fetuin A)}

The molecular weight of a2-HSglycoprotein is 39,300KDa. a2-HSglycoprotein precursor is an inflammation-related calcium regulatory glycoprotein that acts as a systemic calcification inhibitor. Both chronic inflammation and uremia may contribute to exhausting fetuin A release in the late stages of kidney disease. Deficiencies of calcification inhibitors such as fetuin A are relevant to uncontrolled vascular calcification and may offer potential for future therapeutic approaches (Ketteler, M., 2005).

\subsubsection{Vitamin D binding protein (VDBP)}

The molecular weight of vitamin $\mathrm{D}$ binding protein is 52,964KDa. Vitamin D binding protein is a multifunctional protein found in body fluids and on the surface of many cell types. In plasma, it carries vitamin $\mathrm{D}$ sterols and prevents polymerization of actin by binding its monomers. VDBP also associates with membrane bound immunoglobulin on the surface of B lymphocytes and with IgG Fc receptors on the membranes of T lymphocytes, suggesting its possible role in the immunepathogenesis and progression of the disease. Vitamin D binding protein was also found in the vitreous in diabetic macular edema, along with pigment epithelium-derived factor, apoA-4, apoA-1, trip-11, and plasma retinolbinding protein (RBP). These chemical mediators in the posterior vitreous may play a role in the pathogenesis of diabetic macular edema (Ouchi, M., et al 2005).

\subsubsection{Calgranulin B}

The molecular weight of calgranulin is $13,234 \mathrm{KDa}$. Calgranulin B is expressed by macrophages in inflamed tissues and is an inhibitor of protein kinases. Differences in the isoforms and abundance of several urine proteins, including calgranulin B, inter-a-trypsin inhibitor, prothrombin fragment 1, and CD59, were known to be associated with stone formation (Bergsland, K. J., et al 2006). There have been no previous reports on their association with diabetes or other renal diseases. A1AT is an inhibitor of serine proteases, and its primary target is elastase, but it also has a moderate affinity for plasmin and thrombin. The serum levels of A1AT and a a1-acid glycoprotein, as well as their glycosylated protein fractions, were reported to be significantly greater in sera from patients with diabetic nephropathy compared with healthy adults. Marked linear deposition of these proteins in the glomerular or dermal vascular walls was also observed in the same patients (Inoue, W., 1989), linking them to diabetic nephropathy. Whereas the 
association between A1AT deficiency and glomerulonephritis has been reported only sporadically. (Os, I., et al 1997).

\subsubsection{Type IV collagen}

The molecular weight of Type IV collagen is 500,000. Type IV collagen is the major component of the glomerular extracellular matrix and the level of type IV collagen in the urine might reflect the rate of matrix turnover in diseased kidneys. Findings indicate that type IV collagen has a specificity for diabetes nephropathy that albumin itself has not, but since urinary collagen IV is detectable only when microalbuminuria is already present.( Tomino, Y., et al., 2001)

\subsubsection{Podocytes and nephrin}

Podocytes are key structural elements of the glomerular filtration barrier. Podocytes and podocyte-specific proteins can be potentially interesting urinary markers for the early diagnosis of an alteration of the glomerulus.( Dalla Vestra, M., et al 2003) Indeed, urinary podocytes have been detected only in the urine of diabetic patients with micro- and macroalbuminuria, whereas they were absent in healthy controls, type 2 diabetes patients without microalbuminuria or patients suffering from chronic renal failure.( Nakamura, T., et al 2000). Nephrin is one of the many podocyte-specific proteins that have been described in the last few years. nephrin was totally absent in the urine of non-diabetic patients.

\subsubsection{Advanced glycation end products}

Advanced glycation end products (AGEs) are a heterogeneous group of proteins and lipids to which sugar residues are covalently bound during physio-pathological processes.

Kidneys are thought to be one of the key organs for the clearance of AGEs. In type 2 diabetes serum low molecular weight advance glycation end products are usually higher than nondiabetic.( Turk, N., et al., 2004)

\subsubsection{Betaig-h3}

The molecular weight of intact Betaig-h3 is 68KDa. Betaig-h3 is an extracellular matrix protein that is induced by transforming growth factor beta, a growth factor implicated in the pathogenesis of diabetic nephropathy. Ha et al.( Ha, S. W., et al., 2004) first showed that the betaig-h3 to creatinine ratio is significantly higher in type 2 diabetes patients than in control subjects. In another study,( Cha, D. R., et al., 2005) it was also observed that the urinary level of betaig-h3 is higher in diabetic patients (betaig-h3/creatinine ratio: $25.02 \pm 8.84$ ) than in healthy individuals $(18.67 \pm 6.56)$.

\subsubsection{L1 cell adhesion molecule (CD171)}

L1 cell adhesion molecule (CD171) is a potential new marker for tubular injury. It is expressed in human acute kidney injury and excreted in urine. In normal kidney L1 is located in basolateral membrane in all epithelial cells of collecting duct except for intercalated cells. In acute tubular necrosis, L1 lost its polarized distribution and induce in thick ascending limb and distal tubule cells. 


\subsubsection{Tamm-Horsfall protein}

The molecular weight of Tamm-Horsfall protein is $95 \mathrm{KDa}$. It is produced by ascending limb of loop of Henle. It is most prevalent protein and excretion rate is $25-40 \mathrm{mg} /$ day.( Cvoriscec, D., et al., 1985). In renal disease as number of tubules decrease excretion of this protein also accordingly decrease.

\subsection{Downregulated urinary proteins in diabetic nephropathy}

\subsubsection{Transthyretin (prealbumin)}

The molecular weight of transthyretin is $15,877 \mathrm{KDa}$. Transthyretin (prealbumin) is a thyroid hormone-binding protein, which transports a small part of thyroxine from the bloodstream to the brain. About $40 \%$ of plasma transthyretin circulates in a tight complex with plasma RBP. Transthyretin was reported as a better and suitable marker for nutrition assessment in patients with chronic renal failure (Saito, K., et al., 2004). Elevated plasma RBP in insulinresistant humans with obesity and type- 2 diabetes was known to induce hepatic expression of the gluconeogenic enzyme phosphoenolpyruvate carboxykinase and impairs insulin signaling in muscle (Yang, Q., et al., 2005). It is possible that low RBP-4 in diabetic nephropathy increases insulin sensitivity and causes spontaneous hypoglycemia, because low RBP-4 is potentially hypoglycemic. (Riaz, S et al., 2010)

\subsubsection{AMBP proteins}

The molecular weight of AMBP is 38,974KDa. AMBP contains both a1-microglobulin and inter-a-trypsin inhibitor light chain (bikunin). Bikunin is an important anti-inflammatory substance to modulate inflammatory events. Decreases level of this protein affect immunocompetence in diabetic renal disease remains unstudied. The other component of AMBP protein, a1-microglobulin, in urine was directly related to progressive albuminuria in Chinese, Malays, and Asian Indians with type 2 diabetes (Hong, C. Y., et al 2003). This is in contrast to the decreasing levels of this protein observed in our study. Urinary a1microglobulin indicates proximal tubular dysfunction and could be a useful biomarker for the early detection of nephropathy in diabetic subjects in addition to albuminuria, which indicates glomerular dysfunction.

\subsubsection{ApoA-I}

The molecular weight of ApoA-I is 30,759KDa. ApoA-I acting as a cofactor for the lecithin cholesterol acyltransferase, participates in the reverse transport of cholesterol from tissues to the liver for excretion.ApoA1, as well as apoB/A1, was included among several nontraditional cardiovascular risk factors in the progression to pediatric metabolic syndrome (Retnakaran, R., et al., 2006), but there have been no reported references to its association with diabetes or nephropathy. (Riaz, S et al., 2010)

\subsubsection{Adiponectin}

The molecular weight of adiponectin is $28 \mathrm{KDa}$. Adiponectin is an adipocyte-secreted cytokine (adipokine) of human plasma. Decreased adiponectin plasma levels are linked to obesity, insulin resistance and type 2 diabetes. Koshimura et al. found, in the urine of type 2 
diabetes patients with macroalbuminuria, a $30 \mathrm{kDa}$ protein immunoreactive towards an anti-adiponectin monoclonal antibody.( Koshimura, J., et al 2004) Urinary adiponectin may result from the elevation of the serum concentration and enhanced filtration through the damaged kidney. Similar findings were more recently obtained, showing that both serum and urinary adiponectin concentrations are elevated in type 2 diabetes patients with nephropathy, as compared to patients with microalbuminuria alone.( Fujita, H., et al., 2006)

\section{Hypertensive nephropathy}

This is a condition in which kidney damage occur due to chronic blood pressure. In diabetic patients major risk factor for cardiovascular morbidity and mortality is hypertension. (Hypertension in Diabetes Study (HDS) 1993 ; Hansson, L., et al 1998) Diabetic nephropathy develop in $40 \%$ of patients with type 1 diabetes (Krolewski, A. S., et al., 1985) and 35\% of patients with type 2 diabetes (Mehler, P. S., 1997) rigorous treatment of hypertension slow the rate of decrease in renal function and improve mortality (Parving, H. H., et al., 1987 ; Parving, H., and Hommel, E., 1989)

\subsection{Diabetes and hypertension}

Blood pressure, serum lipids and several cardiovascular factors are effected by central adiposity and insulin resistance. (Niaura, R., et al., 2000) Diabetes mellitus and hypertension both are associated with high urinary albumin excretion. In type 2 diabetes patients the presence of microalbuminuria is often a better predictor of cardiovascular disease than of diabetic nephropathy. (Molitch, M. E., et al., 2004) Microalbuminuria is also important marker of atheromatosus and potential of coronary heart disease in diabetic patients. (Donnelly, R., (2002) Recommended target blood pressure in all diabetics is $\leq 130 / 80$ and urinary albumin excretion $>200 \mathrm{mg} / 1$ the goal is $125-130 / 75-80$. (Augustine, J., Donald, G., diabetic nephropathy (2003)

\subsection{Treatment of nephropathy}

Currently ACE inhibitors or ARBs are used for preventing progression of microalbuminurea to macroalbuminurea and advance stages of nephropathy. These drugs have a large amount of adverse effects such as extreme hypotension, hyperkalemia and dry cough which has in certain cases becomes sever enough to stimulate tuberculous cough resulting in wrongful antituberculous treatment being prescribed to the patient. In such a scenario it is important that another biomarker other than microalbuminurea be found for diabetic hypertensive nephropathy which would reveal the development of incipient diabetic nephropathy and a specific drug be designed for that biomarker which would have a fewer side effects as it would be biomarker specific.( Martin- Gallan, et al., (2003).

Type 2 diabetic patients, and same age and sex-matched normal healthy controls were recruited from the Sheikh Zayed Hospital, Lahore, Pakistan. Total Urine and urinary proteins were estimated and analyzed initially by different protein assays and 1-D SDS polyacrylamide gel electrophoresis. The samples were purified further by passing through the high abundance protein removal and desalting columns. These serum and urine samples from control and diabetic groups before or after thiamine therapy were further analysed by 2-D liquid chromatographic system in which samples were initially fractionated by 


\begin{tabular}{|c|c|c|c|c|}
\hline Protein name & $\begin{array}{l}\mathrm{MW} \\
(\mathrm{KDa})\end{array}$ & PI & Function & $\begin{array}{l}\text { Up or down } \\
\text { regulated }\end{array}$ \\
\hline a1-Antitrypsin & 46,707 & 5.52 & $\begin{array}{l}\text { Defense } \\
\text { response }\end{array}$ & + \\
\hline $\begin{array}{l}\text { Serotransferrin } \\
\text { precursor }\end{array}$ & 77,000 & 7.19 & Transport & \\
\hline $\begin{array}{l}\text { Ceruloplasmin } \\
\text { Precursor }\end{array}$ & 122,128 & 5.64 & Transport & + \\
\hline Hemopexin & 51,643 & 6.96 & Transport & \\
\hline AMBP protein & 38,974 & 6.21 & Metabolism & - \\
\hline Complement factor $\mathrm{H}$ & 139,034 & 6.64 & $\begin{array}{l}\text { Defense } \\
\text { response }\end{array}$ & \\
\hline Serum albumin & 71,658 & 6.79 & Transport & + \\
\hline $\begin{array}{l}\text { Alpha1- } \\
\text { Antichymotrypsin } \\
\text { precursor }\end{array}$ & 47,651 & 4.6 & $\begin{array}{l}\text { Defense } \\
\text { response }\end{array}$ & \\
\hline Antithrombin-III & 52,658 & 6.41 & $\begin{array}{l}\text { Defense } \\
\text { response }\end{array}$ & \\
\hline $\begin{array}{l}\text { Complement } \\
\text { component C3 }\end{array}$ & 187,046 & 6.32 & $\begin{array}{l}\text { Defense } \\
\text { response }\end{array}$ & \\
\hline ApoA-1 & 30,759 & 5.72 & Metabolism & - \\
\hline $\begin{array}{l}\text { Alpha2-Glycoprotein } \\
\text { 1, zinc }\end{array}$ & 34,223 & 5.97 & $\begin{array}{l}\text { Defense } \\
\text { response }\end{array}$ & + \\
\hline $\begin{array}{l}\text { Ig gama } 1 \text { chain } \mathrm{C} \\
\text { region }\end{array}$ & 51,628 & 8.1 & $\begin{array}{l}\text { Defense } \\
\text { response }\end{array}$ & \\
\hline Kininogen precursor & 47,853 & 6.64 & $\begin{array}{l}\text { Signal } \\
\text { transduction }\end{array}$ & \\
\hline B-factor, properdin & 68,829 & 6.48 & Metabolism & \\
\hline $\begin{array}{l}\text { Alpha1B- } \\
\text { Glycoprotein }\end{array}$ & 54,239 & 5.82 & FNA & + \\
\hline ApoA-IV & 45,343 & 5.37 & Metabolism & \\
\hline $\begin{array}{l}\text { Haptoglobin } \\
\text { precursor }\end{array}$ & 31,362 & 8.65 & Transport & \\
\hline Clusterin & 52,461 & 6.19 & $\begin{array}{l}\text { Signal } \\
\text { transduction }\end{array}$ & \\
\hline $\begin{array}{l}\text { Beta 2-Glycoprotein } 1 \\
\text { precursor }\end{array}$ & 38,273 & 8.42 & Metabolism & \\
\hline Complement factor B & 85,479 & 7.06 & $\begin{array}{l}\text { Defense } \\
\text { response }\end{array}$ & \\
\hline
\end{tabular}




\begin{tabular}{|c|c|c|c|c|}
\hline Protein name & $\begin{array}{c}\mathrm{MW} \\
(\mathrm{KDa})\end{array}$ & PI & Function & $\begin{array}{l}\text { Up or down } \\
\text { regulated }\end{array}$ \\
\hline Complement factor I & 65,677 & 7.87 & $\begin{array}{l}\text { Defense } \\
\text { response }\end{array}$ & \\
\hline $\begin{array}{l}\text { Complement } \\
\text { component C7 }\end{array}$ & 93,457 & 6.43 & $\begin{array}{l}\text { Defense } \\
\text { response }\end{array}$ & \\
\hline $\begin{array}{l}\text { Hepatocellular } \\
\text { carcinoma associated } \\
\text { protein TB6 }\end{array}$ & 83,232 & 5.69 & Transport & \\
\hline Sulfated glycoprotein 2 & 57,796 & 6.62 & $\begin{array}{l}\text { Signal } \\
\text { transduction }\end{array}$ & \\
\hline Angiotensinogen & 53,121 & 6.22 & $\begin{array}{l}\text { Signal } \\
\text { transduction }\end{array}$ & \\
\hline $\begin{array}{l}\text { Leucine-rich alpha 2- } \\
\text { glycoprotein }\end{array}$ & 38,154 & 6.88 & FNA & \\
\hline $\begin{array}{l}\text { Transthyretin } \\
\text { precursor }\end{array}$ & 15,877 & 5.71 & Metabolism & - \\
\hline $\begin{array}{l}\text { Alpha2-HS- } \\
\text { glycoprotein } \\
\text { precursor } \\
\end{array}$ & 39,300 & 5.64 & Metabolism & + \\
\hline $\begin{array}{l}\text { Prostaglandin H2 D- } \\
\text { isomerase precursor }\end{array}$ & 21,015 & 8.15 & Metabolism & \\
\hline Calgranulin B & 13,234 & 6.04 & $\begin{array}{l}\text { Defense } \\
\text { response }\end{array}$ & + \\
\hline $\begin{array}{l}\text { Complement } \\
\text { component } 9 \\
\text { precursor } \\
\end{array}$ & 63,133 & 5.53 & $\begin{array}{l}\text { Defense } \\
\text { response }\end{array}$ & \\
\hline $\begin{array}{l}\text { Ig alpha }-1 \text { chain } C \\
\text { region }\end{array}$ & 53,163 & 6.06 & $\begin{array}{l}\text { Defense } \\
\text { response }\end{array}$ & \\
\hline $\begin{array}{l}\text { Inter-alpha-trypsin } \\
\text { inhibitor heavy chain } \\
\text { h4 } \\
\text { precursor }\end{array}$ & 101,179 & 6.57 & Metabolism & \\
\hline $\begin{array}{l}\text { Plasma retinol- } \\
\text { binding protein } \\
\text { precursor }\end{array}$ & 22,995 & 5.95 & $\begin{array}{l}\text { Signal } \\
\text { transduction }\end{array}$ & \\
\hline $\begin{array}{l}\text { Epidermal growth } \\
\text { factor-containing } \\
\text { fibulin-like } \\
\text { extracellular matrix } \\
\text { protein }\end{array}$ & 54,517 & 4.99 & $\begin{array}{l}\text { Signal } \\
\text { transduction }\end{array}$ & \\
\hline Hypothetical protein & 52,553 & 7.9 & FNA & \\
\hline
\end{tabular}




\begin{tabular}{|c|c|c|c|c|}
\hline Protein name & $\begin{array}{c}\mathrm{MW} \\
(\mathrm{KDa})\end{array}$ & PI & Function & $\begin{array}{l}\text { Up or down } \\
\text { regulated }\end{array}$ \\
\hline $\begin{array}{l}\text { Predicted } \\
\text { immunoglobulin }\end{array}$ & 23,530 & 7.6 & FNA & \\
\hline Ig k chain $\mathrm{C}$ region & 15,170 & 8.65 & $\begin{array}{l}\text { Defense } \\
\text { response }\end{array}$ & \\
\hline Beta2-microglobulin & 13,706 & 6.45 & $\begin{array}{l}\text { Defense } \\
\text { response }\end{array}$ & \\
\hline $\begin{array}{l}\text { Dystroglycan } \\
\text { precursor }\end{array}$ & 97,520 & 8.9 & Metabolism & \\
\hline Hypothetical protein & 70,309 & 7.9 & FNA & \\
\hline Hypothetical protein & 37,651 & 6.4 & FNA & \\
\hline VDBP & 52,964 & 5.2 & Transport & + \\
\hline $\begin{array}{l}\text { Epididymal secretory } \\
\text { protein E1 }\end{array}$ & 16,559 & 8.04 & $\begin{array}{l}\text { Defense } \\
\text { response }\end{array}$ & \\
\hline $\begin{array}{l}\text { Hypothetical protein } \\
\text { FLJ31320 }\end{array}$ & 67,970 & 8.49 & FNA & \\
\hline Lumican precursor & 38,405 & 6.54 & $\begin{array}{l}\text { Cell } \\
\text { Development }\end{array}$ & \\
\hline $\begin{array}{l}\text { Ig gama4 chain } \mathrm{C} \\
\text { region }\end{array}$ & 35,941 & 8.2 & $\begin{array}{l}\text { Defense } \\
\text { response }\end{array}$ & \\
\hline $\begin{array}{l}\text { Alpha 2-Antiplasmin } \\
\text { precursor }\end{array}$ & 54,531 & 6.2 & $\begin{array}{l}\text { Defense } \\
\text { response }\end{array}$ & \\
\hline ApoA-II precursor & 11,168 & 6.82 & Metabolism & \\
\hline $\begin{array}{l}\text { Fibrinogen beta chain } \\
\text { precursor }\end{array}$ & 55,892 & 8.66 & Metabolism & \\
\hline $\begin{array}{l}\text { Hypothetical protein } \\
\text { FLJ35322 }\end{array}$ & 18,511 & 6.2 & FNA & \\
\hline ApoD & 21,262 & 5.11 & Metabolism & \\
\hline $\begin{array}{l}\text { Corticosteroid- } \\
\text { binding globulin } \\
\text { Precursor }\end{array}$ & 45,112 & 5.93 & Transport & \\
\hline Novel protein & 94,331 & 5.47 & FNA & \\
\hline Vitronectin precursor & 54,306 & 4.6 & $\begin{array}{l}\text { Defense } \\
\text { response }\end{array}$ & \\
\hline $\begin{array}{l}\text { Fibrinogen gama } \\
\text { chain }\end{array}$ & 51,479 & 5.51 & Metabolism & \\
\hline $\begin{array}{l}\text { Hypothetical protein } \\
\text { FLJ22612 }\end{array}$ & 58,511 & 4.62 & FNA & \\
\hline $\begin{array}{l}\text { Ig gama2 chain } \mathrm{C} \\
\text { region }\end{array}$ & 46,032 & 7.88 & $\begin{array}{l}\text { Defense } \\
\text { response }\end{array}$ & \\
\hline
\end{tabular}

Table 1. Urinary protein identified in type 2 diabetic patients with macroalbuminuria (Riaz, S. 2009, 2010, 2011) 
chromatofocusing and the selected fractions were further analysed by reverse-phase high performance liquid chromatography. The proteins which showed variation between test and control samples were identified by mass spectrometry MALDI TOF/TOF and LC MS analysis. All the samples belonging to the control and diabetic groups were then analyzed by ELISA and estimated the levels of some proteins which were found to vary. (Samreen Riaz, 2009,2010, 2011)

\section{References}

American diabetes association diabetic nephropathy diabetic care 2002; 25 (supplement).

Atkinson, M. A., Maclaren, N. K., (1994). The pathogenesis of insulin dependent diabetes. N Engl J Med 331:1428-1436.

Atkinson, M. A., Maclaren, N.K., Riley, W.J., Winter, W.E., Fisk, D.D., Spillar, R.P., (1986). Are insulin autoantibodies markers for insulin-dependent mellitus? Diabetes 35: 894-898.

Augustine, J., Donald, G., diabetic nephropathy (2003). The Cleveland Clinic, Department of nephrology and Hypertension, The Cleveland Health Foundation, United States.

Baekkeskov, S., Neilsen, J. H., Marner, B., Bilde, T., Ludvigsson, J., Lernmark, A., (1982). Autoantibodies in newly diagnosed diabetic children with immunoprecipitate human pancreatic islet cell proteins. Nature 298: 167-169.

Banerji, M. A., Chaiken, R. L., Huey, H., Tuomi, T., Norin, A. J., Mackay, I. R., Rowley, M. J., Zimmet, P., Lebovitz, H., (1994). GAD antibody negative NIDDM in adults black subjects with diabetic ketoacidosis and increased frequency of human leukocyte antigen DR3 and DR4. Diabetes 43:741-745.

Banerji, M., Lebovitz, H., (1989). Insulin sensitive and insulin resistant variants in IDDM. Diabetes 38:784-792.

Barnett, A. H., Eff, C., Leslie, R. D. G., Pyke, D. A., (1981). Diabetes in identical twins. Diabetologia 20:87-93.

Barrett, T. G., Bundey, S. E., Macleod, A. F., (1995). Neurodegeneration and diabetes: UK nation wide study of Wolfrm (DIDMOAD) syndrome. Lancet 346:14581463.

Berelowitz, M., and Eugene, H.G., (1996). Non-insulin dependent diabetes mellitus secondary to other endocrine disorders. In Diabetes Mellitus. LeRoith D, Taylor SI, Olefsky JM, Eds. New York, Lippincott-Raven, p.496-502

Bergsland, K. J., Kelly, J. K., Coe, B. J., Coe, F. L., 2006. Urine protein markers distinguish stoneforming from non-stone-forming relatives of calcium stone formers. Am J Physiol 291:F530-F536.

Bogardus, C., Lillioja, S., Mott, D. M., Hollenbeck, C., Reaven, G., (1985). Relationship between degree of obesity and in vivo insulin action in man. Am J Physiol 248:E286-E291.

Cersosimo, E., Pister, P. W. T., Pesola, G., McDermott, K., Bajorunas, D., Brennan, M. F., (1991). Insulin secretion and action in patients with pancreatic cancer. Cancer 67:486-493. 
Cha, D. R., Kim, I. S., Kang, Y.S., et al. (2005). Urinary concentration of transforming growth factor-beta-inducible gene-h3(beta ig-h3) in patients with Type 2 diabetes mellitus. Diabet Med 22:14-20.

Christensen, E. I. (2002). Pathophysiology of protein and vitamin handling in the proximal tubule. Nephrol. Dial. Transplant. 17, Suppl. 9, 57-58.

Clement, K., Pueyo, M. E., Vaxillaire, M., Raketoambinina, B., Thuillier, F., Passa, P., Froguel, P., Roberts, J., Velho, G., (1996). Assessment of insulin sensitivity in glucokinase-deficient subjects. Diabetologia 39: 82-90.

Cousins, L., 1995. Obstetric complications. In Diabetes Mellitus and Pregnancy: Principles and Practice. 2nd ed. New York, Churchill Livingstone, p. 455-468.

Dalla Vestra, M., Masiero, A., Roiter, A. M., et al (2003). Is podocyte injury relevant in diabetic nephropathy? Studies in patients with type 2 diabetes. Diabetes 52:10311035.

Defronzo, R., Deibert, D., Hendler, R., Felig, P., (1979). Insulin sensitivity and insulin binding to monocytes in maturity-onset diabetes. J Clin Invest 63:939-946.

Diabetes: Could vitamin 'B' the answer? Chloë Harman Comments on Original article, Naila Rabbani, Saadia Shahzad Alam, Samreen Riaz, James Larkin, M Waheed Akhtar, Tahir Shafi and Paul J Thornalley. High dose thiamine therapy for people with type 2 diabetes and microalbuminuria: a randomised, doubleblind, placebo-controlled study. Diabetologia 52, 208-212 (2009). Nature Reviews Endocrinology (5), 236-236 (30 April 2009) doi:10.1038/nrneph.2009.8 Research Highlights (Impact factor 3.76 ). http://www.Nature.com/ review endocrinology/ htm.

Diabetes: Could vitamin 'B' the answer? Chloë Harman Comments on Original article, Naila Rabbani, Saadia Shahzad Alam, Samreen Riaz, James Larkin, M Waheed Akhtar, Tahir Shafi and Paul J Thornalley. High dose thiamine therapy for people with type 2 diabetes and microalbuminuria: a randomised, double-blind, placebo-controlled study. Diabetologia 52, 208-212 (2009). Nature Reviews Nephrology 5, 182 (April 2009) doi:10.1038/nrneph.2009.8. Research Highlights (Impact factor 4.764). http://www.Nature.com/ review enephrology/ htm.

Forrest, J.A., Menser, M.A., Burgess, J.A., (1971). High frequency of diabetes mellitus in young patients with congenital rubella; Lancet ii:332-334.

Fujita, H., Morii, T., Koshimura, J., et al. (2006). Possible relationship between adiponectin and renal tubular injury in diabetic nephropathy. Endocr J 53:745-752.

Group TMCS (the Microalbuminuria Collaborative Study Group) (1999). Predictors of the development of microalbuminuria in patients with Type 1 diabetes mellitus: a seven-year prospective study. Diabet Med 16:918-925.

Ha, S. W., Kim, H. J., Bae, J. S., et al. (2004). Elevation of urinary betaig-h3, transforming growth factor-beta-induced protein in patients with type 2 diabetes and nephropathy. Diabetes Res Clin Pract 65:167-173.

Hansson, L., Zanchetti, A., Carruthers, S. G., Dahlof, B., Elmfeldt, D., Julius, S., Menard, J., Rahn, K. H., Wedel, H., Westerling, S., 1998. Effects of intensive blood-pressure lowering and low-dose aspirin in patients with hypertension: principal results of 
the Hypertension Optimal Treatment (HOT) randomized trial. Lancet 351:17551762.

Herman, W. H., Fajans, S. S., Oritz, F. J., Smith, M. J., Sturis, J., Bell, G. I., Polonsky, K. S., Halter, J. B., (1994). Abnormal insulin secretion, not insulin resistance, is the genetic or primary defect of MODY in the RW pedigree. Diabetes 43:40-46.

Hong, C. Y., Hughes, K., Chia, K. S., Ng, V., Ling, S. L., 2003. Urinary a1-microglobulin as a marker of nephropathy in type 2 diabetic Asian subjects in Singapore. Diabetes Care 26: 338-342.

Hypertension in Diabetes Study (HDS) 1993. Increased risk of cardiovascular complications in hypertensive type 2 diabetic patients. J Hypertens 11:319-325.

Inoue, W., 1989. Immunopathological analysis of acute phase reactant (APR) proteins in glomeruli from patients with diabetic nephropathy. Nippon Jinzo Gakkai Shi 31: 211219.

Jadresic, A., Banks, L. M., Child, D. F., Diamant, L., Doyle, F. H., Fraser, T. R., Joplin, G. F., (1982). The acromegaly syndrome. J Med202:189-204.

Jain, S., Rajput, A., Kumar, Y., Uppuluri, N., Arvind, A. S., Tatu, U., 2005. Proteomic analysis of urinary protein markers for accurate prediction of diabetic kidney disorder. $J$ Assoc Physicians India 53:513-520.

Kahn, C. R., Flier, J. S., Bar, R. S., Archer, J. A., Gorden, P., Martin, M.M., Roth, J., (1976). The syndromes of insulin resistance and acanthosis nigricans. N Engl J Med 294:739745.

King, H., Rewers, M., (1993). Global estimates for prevalence of diabetes mellitus and impair glucose tolerance in adults: WHO Ad Hoc Diabetes Report Group. Diabetes Care 16:157-177.

King, M. L., Bidwell, D., Shaikh, A., Voller, A., Banatvala, J. E., (1983). Coxsackie-B-virusspecific IgM responses in children with insulin-dependent (juvenile-onset; type 1) diabetes mellitus. Lancet i:1397-1399.

Koshimura, J., Fujita, H., Narita, T. (2004). Urinary adiponectin excretion is increased in patients with overt diabetic nephropathy. Biochem Biophys Res Commun 316:165169.

Krolewski, A. S., Warram, J. H., Chrislieb, A., Busick, R. J., Kahn, C. R., 1985. The changing natural history of nephropathy in type 1 diabetes. Am J Med 78:785-794.

Lan, M. S., Wasserfall, C., Maclaren, N. K., Notkins, A. L., (1996). 1A-2, a transmembrane protein of the protein tyrosine phosphatase family, is a major autoantigen in insulindependent diabetes mellitus. Proc Natl Acad Sci USA 93:6367-6370.

Larsen, S., Hilsted, J., Tronier, B., Worning, H., (1987). Metabolic control and B cell function in patients with insulin-dependent diabetes mellitus secondary to chronic pancreatitis. Metabolism 36:964-967.

Lu, J., Li, Q., Xie, H., Chen, Z., Borovitskaya, A. E., Maclaren, N. K., Notkins, A.L., Lan, M. S., (1996). Identification of a second transmembrane protein tyrosine phosphatase, $1 \mathrm{~A}-2 \beta$, as an autoantigen in insulin-dependent diabetes mellitus: precursor of the 37-KDa tryptic fragment. Proc Natl Acad Sci USA 93: 2307-2311. 
Magee, M.S., Walden, C.E., Benedetti, T.J., 1993. Influence of diagnostic criteria on the incidence of gestational diabetes and perinatl morbidity. JAMA 269:609-615.

Mehler, P. S., Jeffers, B. W., Estacio, R., Schrier, R. W., 1997. Association of hypertension and complications in non-insulin dependent diabetes mellitus. Am J Hypertens 10:152161.

Molitch, M. E., DeFronzo, R. A., Franz, M. J., Keane, W. F., Mogensen, C. E., Parving, H. H., Steffes, M. W., (2004). Nephropathy in diabetes (position statement). Diabetes Care 27 (Suppl 1):S79-S83.

Naila Rabbani, Saadia Shahzad Alam, Samreen Riaz, James Larkin, M Waheed Akhtar, Tahir Shafi and Paul J Thornalley. 2009. High dose thiamine therapy for people with type 2 diabetes and microalbuminuria: a randomised, double-blind, placebocontrolled study. Diabetologia. Springer Berlin / Heidelberg. Vol. 52 (2), 208-212. (Impact factor 5.822) http://www.springerlink.Journal Issue/ Diabetologia/htm. PubMed.

Samreen Riaz, "Study of Protein Biomarkers for Diabetes Mellitus Type 2 and Role of High Dose Thiamine on their Level" Advances in Medicine and Biology (2010). Editor, Leon V Berhardt. Book Hauppauge, N.Y. 11788-3619, USA. Phone (631) 231-7269 * Fax (631) 299-0165. http://www.novapublishers.com. I: \Nova publishs $\backslash$ Advances in Medicine and Biology_Volume 13.htm.Chapter 11. Volume 13. Nova Science Publishers, Inc. 400 Oser Avenue, Suite 1600,

Nakamura, T., Ushiyama, C., Suzuki, S., et al. (2000). Urinary excretion of podocytes in patients with diabetic nephropathy. Nephrol Dial Transplant 15:1379-1383.

Newman, B., Selby, J. V., Slemenda, C., Fabsitz, R., Friedman, G. D., (1987). Concordance for type 2 (non-insulin-dependent)diabetes mellitus in male twins. Diabetologia 30: 763-738.

Niaura, R., Banks, S. M., Ward, K. D., et al. 2000. Hostility and metabolic syndrome in older males. The normative aging study. Psych Som Med; 62:7-16

O'Byrne. S., and Feely, J., (1990). Effects of drugs on glucose tolerance in non-insulindependent diabetes (part 1 and 2). Drug 40: 203-219.

Olesfsky, J. M., Kolterman, O. G., Scarlett, J. A., (1982). Insulin action and resistance in obesity and noninsulin-dependent tye 2 diabetes mellitus. Am J Physiol 243:E15E30.

Os, I., Skjorten, F., Svalander, C., Berge, E., 1997. a1-Antitrypsin deficiency associated with hepatic cirrhosis and IgA nephritis. Nephron 77:235-237.

O'Sullivan, J. B., Mahan, C. M., (1994). Criteria for the oral glucose tolerance test in pregnancy. Diabetes 13:278.

Ouchi, M., West, K., Crabb, J. W., Kinoshita, S., Kamei, M., 2005. Proteomic analysis of vitreous from diabetic macular edema. Exp Eye Res 81:176 -182.

Pak, C.Y., Eun, H., McArthur, R.G., Yoon, J., (1988). Assocition of cytomegalovirus-infection with autoimmune type 1 diabetes. Lancet ii:1-4.

Pandit, M. K., Burke, J., Gustafson, A. B., Minocha, A., Peiris, A. N., (1993). Drug-induced disorders of glucose tolerance. Ann Int Med 118:529-540. 
Parving, H. H., Andersen, A. R., Smidt, U. M., Hommel, E., Mathiesen, E. R., Svendsen, P. A., 1987. Effect of antihypertensive treatment on kidney function in diabetic nephropathy. BMJ 294:1443-1452.

Parving, H., Hommel, E., 1989. Prognosis in diabetic nephropathy. BMJ 299:230-233.

Pisitkun, T., Shen, R. F., and Knepper, M. A. (2004) Identification and proteomic profiling of exosomes in human urine. Proc. Natl. Acad. Sci. U. S. A. 101, 1336813373.

Rabbani, N., Shahzad Alam, S., Riaz, S., Larkin, J.R., Akhtar, M.W., Shafi, T. and Thornalley, P.J. Response to comment on Rabbani et al., (2009) High dose thiamine therapy for patients with type 2 diabetes and microalbuminuria: a pilot randomised, doubleblind, placebo-controlled study. Diabetologia, 52(2): 208 - 212, 2009. Diabetologia. 52 (6): 1214-1216. (Impact factor 5.822) http://www.springerlink.Journal Issue/ Diabetologia/htm. PubMed.

Reaven, G. M., Bernstein, R., Davis, B., Olefsky, J. M., (1976). Nonketotic diabetes mellitus: insulin deficiency or insulin resistnce? Am J Med 60:80-88.

Retnakaran, R., Zinman, B., Connelly, P. W., Harris, S. B., Hanley, A. J., 2006. Nontraditional cardiovascular risk factors in pediatric metabolic syndrome. $J$ Pediatr 148:176-182.

Rimoin, D. L., (1976). Genetic syndromes associated with glucose intolerance. In The Genetics of Diabetes Mellitus. Berlin Springer-Verlag.

Saito, K., Shimizu, A., Inoue, S., Hamada, C., Fukui, M., Tomino, Y., 2004. Effective usage of nutrition assessment proteins in patients with diabetic nephropathy. Nippon Jinzo Gakkai Shi 46:73-78.

Samreen Riaz, Saadia Shahzad Alam and M. Waheed Akhtar. (2010). Proteomic Identification of human serum biomarkers in diabetes mellitus type-2. Journal of Pharmaceutical and Biomedical Analysis. Volume 51 issue 5, 1103-1107.

Samreen Riaz, Diabetes mellitus (Review article) Scientific Research and Essay. Vol. 4 (5) pp. 367-373, May, 2009.

Samreen Riaz, Mehreen Raza, Saadia Shhazad Alam, Shahida Hasnain and M. Waheed Akhtar. 2009. Obesity as risk factor and study of obesity related proteins in diabetes mellitus. African Journal of Biotechnology Vol. 8 (5), pp. 737-744, 6 March, 2009. (Impact factor 0.456)

Samreen Riaz, Saadia Shahzad Alam, Surjit Kaila Srai, Vernon Skinner, Aasma Riaz and M. Waheed Akhtar. (2010). Proteomic Identification of human urine biomarkers in diabetes mellitus type-2. Journal of Diabetes technology \& Therapeutics. 2010. 12 (12): 979- 988. (Impact factor 2.620).

Samreen Riaz, Vernon Skinner and Surjit Kaila Srai. (2011). Effect of high dose thiamine on levels of human urine protein biomarkers in diabetes mellitus type 2. Journal of Pharmaceutical and Biomedical Analysis. JPBA-D-10-01119. Volume / issue. . (Impact factor 2.453).

Samreen Riaz and Ansa Butt (2010). Study of Protein profiling of human urine in diabetic hypertensive nephropathy versus normal healthy controls. Diabetes technology \& Therapeutics.. 12 (5): 379-386 
World Health Organization: Diabetes Mellitus: Report of a WHO Study Group. Geneva, World Health Org., 1985 (Tech Rep Ser, no. 727) 


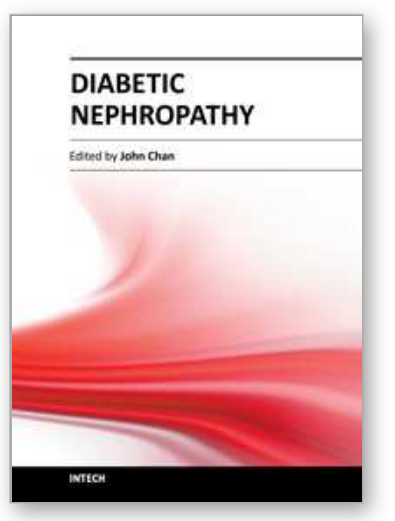

\author{
Diabetic Nephropathy \\ Edited by Dr. John Chan
}

ISBN 978-953-51-0543-5

Hard cover, 166 pages

Publisher InTech

Published online 20, April, 2012

Published in print edition April, 2012

Internationally renowned experts have provided data on their own studies, and discuss the relative usefulness of their work in relation to diabetic nephropathy. The first section describes the novel role of intrarenal reninangiotensin-aldosterone system (RAAS) and oxidative stress in the development of diabetic nephropathy and discusses the current and novel pharmacological interventions in the treatment of diabetic nephropathy. The second section discusses other important contributors outside of the RAAS in the pathogenesis of diabetic nephropathy including AGE/RAGE, epithelial-mesenchymal-transition (EMT) and immune cytokines. Features: Provides novel information on various pathophysiological determinants in the development of diabetic nephropathy Provides novel information on various pharmacological interventions of diabetic nephropathy

\title{
How to reference
}

In order to correctly reference this scholarly work, feel free to copy and paste the following:

Samreen Riaz and Saadia Shahzad Alam (2012). Study of Diabetic Hypertensive Nephropathy in the Local Population of Pakistan, Diabetic Nephropathy, Dr. John Chan (Ed.), ISBN: 978-953-51-0543-5, InTech,

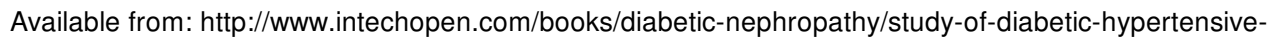
nephropathy-in-the-local-population-of-pakistan-

\section{INTECH}

open science | open minds

\section{InTech Europe}

University Campus STeP Ri

Slavka Krautzeka 83/A

51000 Rijeka, Croatia

Phone: +385 (51) 770447

Fax: +385 (51) 686166

www.intechopen.com

\section{InTech China}

Unit 405, Office Block, Hotel Equatorial Shanghai

No.65, Yan An Road (West), Shanghai, 200040, China

中国上海市延安西路65号上海国际贵都大饭店办公楼405单元

Phone: +86-21-62489820

Fax: $+86-21-62489821$ 
(C) 2012 The Author(s). Licensee IntechOpen. This is an open access article distributed under the terms of the Creative Commons Attribution 3.0 License, which permits unrestricted use, distribution, and reproduction in any medium, provided the original work is properly cited. 